\title{
Comunitatea ortodoxă românească din Sofia. Istorie și actualitate
}

\author{
Andrian ALEKSANDROV*
}

\begin{abstract}
The Romanian Orthodox Community of Sofia. Its History and its Present. This article is a short passage throughout the history of the Romanian diaspora, the Romanian schools, and the Romanian Orthodox Church in Sofia. The Romanian community in Sofia is formed by two components: 1) the Aromanian diaspora, who arrived in Sofia in the second part of the nineteenth century, and 2) Romanian citizens who have married or worked in the Bulgarian capital. They were all Orthodox Christians who shared the same faith. That is why one of the first things they did was to organize a religious community, or parish. Their second goal was to create a single school so that they could keep their identity in a capital multiethnic and cosmopolitan city. As a result, the history of the Romanian diaspora is inextricably linked to the history of the Romanian parish in Sofia and the history of Romanian schools. For this reason, we present them in parallel.
\end{abstract}

Keywords: Romanian diaspora, Romanian Orthodox Church, Sofia, aromanians.

Subiectul acestui studiu îl constituie istoria comunităţii românești din Sofia (Bulgaria). Scopul studiului de față este acela de a analiza dezvoltarea sa istorică și formarea treptată, precum și starea sa actuală. Principalul motiv al tratării acestui subiect este în mare măsură unul de natură emoțională, deoarece, timp de 11 ani, ca student și, ulterior, după finalizarea studiilor (1992-2003), am locuit în incinta complexului parohial al Bisericii Române din

\footnotetext{
* Conferențiar universitar la Facultatea de Teologie Ortodoxă, Universitatea „Sfântul Clement al Ohridei” din Sofia, Bulgaria.
} 
Sofia. Acolo am făcut cunoştință cu o mare parte a diasporei românești, cu ai cărei membri am menținut legătura până în prezent.

\section{Formarea și dezvoltarea istorică a comunității românești din Sofia}

Una dintre primele constatări asupra prezenței elementului românesc la Sofia este identificată în notele istorice a lui Petre Bogdan Bacșev, din anul 1640, care scrie: „Orașul Sofia este situat pe drumul de trecere și este în mijlocul țării și, de aceea, este un oraș comercial unde se întâlnesc oameni din Ungaria, Muntenia, Moldova și chiar din Polonia"1. La aceștia trebuie să adăugăm mulți negustori aromâni (macedoromâni). Comerțul pe care macedoromânii îl făceau în diferitele centre din Peninsula Balcanică i-a determinat pe mulți din aceștia să se așeze la Sofia. Mai târziu s-au așezat definitiv o mulțime de migranți aromâni din Macedonia și Albania, fapt despre care avem dovezi încă de la începutul secolului al XIX-lea ${ }^{2}$. Așa s-a format o numeroasă comunitate aromână care a luat parte la viața economică, politică, socială și culturală a orașului.

O proporție însemnată a românilor din Sofia este strâns legată de Principatele Române şi de comunităţile românilor macedonieni de peste Dunăre. O parte dintre ei au venit din Macedonia și Albania și s-au stabilit întâi la nordul Dunării, iar după un timp s-au aşezat la Sofia ${ }^{3}$. În mare parte, românii din Sofia

1 Vezi: Eusebius Martin Fermendzin, Acta Bulgariae Ecclesiastica, Zagrebae, 1887, p. 73.

${ }^{2}$ Николай Кюркчиев, Армъните - етнос и език с 2000 годишна история, în Toma KIURKCIEV / Nicolay KIURKCIEV, Istoria comunității românești din Sofia - Prezentare istorică, acte, evenimente, Sofia, 2001, p. 11.

${ }^{3}$ Un caz asemănător este familia fraților Dimce și Târpu Ciomu, care în $1860 \mathrm{~s}$-au mutat din Craiova la Sofia. Tot din această familie este și marele negustor Gachi (Ghachi, Gaki) Trifon, care a luat parte la eliberarea Bulgariei, iar în primăvara anului 1878 a fost unul dintre cei trei membri ai orașului Sofia sub ministeriatul marelui cărturar bulgar Marin Drinov (Vezi Vasile HRISTU, „Comunitatea românească din Sofia”, în Toma KIURKCIEV / Nicolay KIURKCIEV, op.cit., p. 71). 
au venit din comunele aromâne din Moloviște, Gopeși şi Cruşova, iar o parte mai mică din Tarnova, Magarova, Bitola şi Moscopole ${ }^{4}$, Gramos, Știp, Tetova etc., pentru a căuta locuri de muncă şi un trai de viaţă mai bun. Păstorii aromâni, precum şi bulgarii, îi numesc pe cei din orașe ,țințari”, spre deosebire de aromânii păstori nomazi care au fost numiți „kuțovlasi” sau „karakaciani”. Oricum, această deosebire are doar un caracter social ${ }^{5}$. Ulterior, s-au adăugat şi românii, veniți în Sofia din localitățile situate de-a lungul Dunării de Sud, în Valea Timocului sau în celelalte orașe din Bulgaria cu populație românească, precum şi românii proveniţi din căsătorii mixte sau cei veniți în Sofia la muncă.

După eliberarea Bulgariei de sub stăpânire turcească din anul 1878, mulți români din Macedonia și-au adus familiile lor la Sofia și s-au așezat definitiv în nouă capitală a Bulgariei. Unii dintre ei sunt purtători de educație și cultură românească, ca rezultate ale Renașterii Aromâne, care se bazează pe conștientizarea originii romanice comune și apropierea de românii de la nordul Dunării ${ }^{6}$. În acest fel, comunitatea românească a crescut constant. Mulți ani la rând, românii din Sofia erau grupați după locurile lor de naștere, până în anul 1893, când a luat ființă Societatea „Unirea”, care-i reprezintă pe toți ${ }^{7}$.

După Primul Război Mondial avea să înceapă reorganizarea comunității românești din Sofia. În anul 1923 a luat ființă un nou aşezământ cultural și social - Societatea Tinerilor Aromâni, cu sediul în incinta școlii românești. În aceeași perioadă s-a format și Societatea Femeilor românce, având ca scop întrajutorarea celor în nevoi. Pentru dezvoltarea culturii morale și naționale a fost înființată o școală de adulţi pentru studierea limbii, literaturii și culturii române. Societatea femeilor românce a deținut cele mai bogate fonduri, prin care au reușit să întrețină o cantină școlară, au acordat premii elevilor silitori, au distribuit îmbrăcăminte și

\footnotetext{
${ }^{4}$ Vasile Hristu, op.cit., p. 72.

5 Vezi А. Кирилова, Родовата памет на армъните, В: Георгиева, Ив. /съст./. Армъните в България. С., 1998, с. 29.

${ }^{6}$ Николай Кюркчиев, Пос. съч., с. 18.

${ }^{7}$ Vasile HRISTU, op.cit., p. 75.
} 
încălțăminte elevilor săraci, au ajutat cu bani familiile cu posibilităţi financiare reduse din Sofia, izbutind, totodată, să cumpere obiecte necesare pentru școală și biserică ${ }^{8}$.

Această situație a fost prezentă până în luna octombrie a anului 1937, când a fost convocată o mare adunare a celor trei societăți românești din Sofia: Societatea Comunității Românești, Societatea Femeilor Românce și Societatea Tineretului Român. La respectiva adunare s-a hotărât ca cele trei organizații să funcționeze împreună și să poarte numele de ,Societatea Comunității Românești din Sofia - Unirea". În aceeași lună, comitetul de conducere a adresat un apel către toți românii macedoneni din Sofia și din Bulgaria, în care a fost expus un program privitor la activitatea culturală, păstrarea obiceiurilor și datinilor românești, precum și educarea aromânilor în limba română literară9 .

Încă din anii 1928-1929, aromânii au început să emigreze în România, iar acest proces a continuat până în anul 1940, lăsând urme vitrege asupra comunității românești din Sofia. Astfel, multe familii s-au împărțit, o parte stabilindu-se în România, iar cealaltă rămânând în Bulgaria. În aceste condiții, comunitatea s-a micşorat considerabil și nu a putut să își mai revină ${ }^{10}$. Deși într-o formă restrânsă, comunitatea românească și-a continuat activitatea și în anii următorii, însă din octombrie 1948, când au încetat să funcționeze școlile românești din Sofia, românii care erau legați de școală n-au mai putut să își desfășoare activitatea. Totuși, ea continuă să existe, unită în jurul Bisericii românești, în care activitatea liturgică nu a încetat niciodată, începând din perioada comunismului și continuând până în prezent. După anul 1948, organizațiile aromâne au fost desfiinţate ${ }^{11}$, iar în comunitatea românească se organizează o nouă asociație culturală și educativă numită „Nicolae Bălcescu”"12.

Înainte de anul 1960, după buletinul de identitate, aromânii sunt înscriși ca valahi, iar ulterior ca bulgari. Datorită căsătoriilor mixte,

\footnotetext{
${ }^{8}$ Ibidem, p. 84-85.

${ }^{9}$ Ibidem, p. 85-86.

${ }^{10}$ Николай Кюркчиев, Пос. съч., с. 19.

${ }^{11}$ Ibidem, p. 20.

${ }^{12}$ Vasile HRISTU, op.cit., p. 92.
} 
numărul de persoane cu identitate aromână a început să scadă, diminuându-se rapid. Astfel, în anul 1992, pentru a înceta procesul de asimilare a acestora, a fost restaurată la Sofia Asociaţia Aromână (Sutsata Armânjlor) ${ }^{13}$. Scopul principal al asociației a fost deschiderea unei școli românești în Sofia, în care să existe posibilitatea de a studia şi în limba aromână. Obiectivele acestei asociații au fost păstrarea limbii, obiceiurile, folclorul aromân şi menținerea legăturii cu organizațiile aromâne din statele balcanice vecine ${ }^{14}$.

Trecând prin diferite obstacole, comunitatea românească a păstrat loialitatea față de statul bulgar, fiind, totodată, şi o legătură naturală între statele şi popoarele vecine şi prietene, român şi bulgar. În acest context este bine să amintim că prima legătură diplomatică între regatul Român şi principatul Bulgar a fost înlesnită de faptul că marele aromân Ghachi Trifon Ciomo (1837-1916) a pus la dispoziție o casă pentru Agenția Diplomatică Română ${ }^{15}$. Tot în acest sens, este interesant să menționăm faptul că în toamna anului 1916, în ciuda faptului că Bulgaria şi România sunt opuse ca state şi forțe militare, comunitatea românească din Sofia a pregătit un loc, în centrul cimitirului central, spre a fi depuse trupurile neînsuflețite ale soldaților din Armata română, căzuți ca eroi în împrejurimile orașului Sofia. Mai târziu, a fost ridicat şi monumentul care este îngrijit până astăzi cu respect, unde, în fiecare an, la praznicul Înălțării Domnului, precum și de Ziua Armatei, se săvârșesc slujbe religioase de comemorare pentru eroii neamului.

\section{2. Înființarea și scurta istorie a școlii românești din Sofia}

Prima societate aromână „Unirea” a avut ca scop principal dezvoltarea de activităţi educaţionale şi culturale ${ }^{16}$, prin zidirea de

13 Vezi Protocolul din 4 octombrie 1992, în Георги Барболов. Историята на армъните и взаимоотношенията им с българите. С., 2000, p. 136.

14 Николай Кюркчиев, Пос. съч., с. 23-24.

${ }^{15}$ Vasile Hristu, în Toma KiURKCIEV / Nicolay KiURKCIEv, op.cit., p. 8.

${ }^{16}$ Mai multe detalii vezi în Нягулов, Б. Проблемът за власите в България между двете световни войни: политически фактори и аспекти, В: Българска етнология. Г. XXI, извънреден брой, С. 1955. с. 52-74; I. G. GHIULAMILA, 
clădiri pentru şcoala şi biserica românească. ${ }^{17}$ În data de 11 mai 1895, în cadrul unei ședințe a societății, s-a luat decizia înființării unei școli românești. Astfel, toate fondurile societăților românești din Sofia au fost prevăzute pentru cumpărarea unui teren necesar pentru ridicarea clădirii școlii. Această idee a fost preluată de către Ministerul Învățământului din București, astfel că la data de 1 septembrie 1895 au fost înființate două școli primare românești: una de fete și una de băieți, ambele unităţi de învăţământ având aproximativ 100 de elevi.

Primul director al şcolii, Dinu Lazărescu Lecanta, trimis de Ministerul Învățământului din București, a fost primit cu mare bucurie şi deosebită atenţie de către toți membrii comunității ${ }^{18}$. La doi ani după hotărârea de a se înființa o școală românească, la 11 mai 1897, o comisie de români din Sofia, alcătuită din persoanele cele mai marcante ale comunității, a hotărât să fie achiziţionat un teren între străzile de azi „Ekzarh Iosif”, „Kniaz Boris I” şi „Piritska”. Proiectul arhitectural al școlii a fost încredințat celebrului arhitect austriac Friedrich Grunanger, care a construit o serie de clădiri emblematice pentru orașul Sofia de la sfârșitul secolului XIX și începutul secolului XX. Întrucât terenul s-a dovedit a fi insuficient, între anii 1908 și 1909, s-au cumpărat mai multe proprietăți de pe aceeași stradă și, astfel, s-a format un teren comun de 2964,69 $\mathrm{m}^{2}$. Actele originale se aflau în arhivele Legației României la Sofia. Ideea primordială era cea a edificarea unei biserici românești, lucru care s-a înfăptuit și care a durat mult timp, în timp ce construirea școlii a fost amânată pe moment.

În anul 1920, activitatea școlilor şi organizaţiilor românești a fost în creștere. În 1923 a fost înființară o asociație a tinerilor aromâni, cu sediul la Sofia, scopul principal al acesteia fiind menținerea limbii aromâne, precum şi a tradițiilor şi obiceiurile aromâne. Rolul Statului Român, cu sprijinul lui material şi politic,

„Românii macedonieni din Bulgaria (Aromânii)”, în Graiul Românesc, 2/1928, p. 28; Vasile HRISTU, Aromânii din Bulgaria, în Graiul Românesc, 6-7/1931, p.

86; Gh. BANDU, „Aromânii din Sofia”, în Deșteptarea, 12/1992.

${ }^{17}$ Vasile Hristu, în Toma KIURKCIEV / Nicolay KIURKCIEV, op.cit., p. 53.

${ }^{18}$ Ibidem, p. 8, 18. 
a fost unul neprețuit. În anul 1880, înaintea deschiderii școlii din Sofia, a fost inaugurată o şcoală română în orașul Gorna Djumaia (azi Blagoevgrad). Administrarea școlilor românești din Bulgaria este realizată cu ajutorul Legației din Sofia. Şcoala română de la Gorna Djumaia rămâne primară, pentru ca cea de la Sofia să de dezvolte în continuare. În anul 1924, se deschide ca școală generală, pentru ca zece ani mai târziu să se transforme în liceu. Anul 1934 este de o mare importanță pentru comunitatea românească, când Liceul român din Sofia a fost ridicat la rangul de Institut Român, având şi bucuria de a folosi o nouă clădire, pe strada Exarh Iosif. Institutul a devenit un centru de promovare a culturii românești în Bulgaria. Activitatea acestora a continuat până în toamna anului 1948, când liceul şi Institutul Român din Sofia au încetat să mai funcționeze. Ulterior, clădirea acestuia, împreună cu sala de gimnastică (anexă), au fost date în folosința statului bulgar ${ }^{19}$.

La 16 septembrie 1999, a fost redeschis Liceul român „Mihai Eminescu” din Sofia, dar nu în vechea clădire, care între timp a fost vândută statului bulgar, ci în incinta clădirii unei şcoli municipale din Sofia. Astăzi, Liceul din Sofia funcţionează ca unitate şcolară pentru studierea intensivă a limbii române ${ }^{20}$. În prezent, clădirea școlii este situată pe strada Rakovska, lângă staţia de metrou „Lavov most”, care oferă condiții excelente studenților. Școala, cu predare în limba română - limbă care stârnește un interes scăzut pentru tinerii bulgari -, începe cu clase mici de 5-8 elevi, dezvoltându-se de-a lungul anilor cu clase mai mari, până la terminarea liceului. În anul 2021, în școală se preda intensiv limbile română, engleză și, opțional, limbă spaniolă, urmând ca din anul școlar 2021-2022 să fie inclusă și limba greacă. Școala are deja două clase în anul de curs, una cu profil „Română” și cealaltă cu profil „Antreprenoriat”. Majoritatea elevilor erau bulgari, foarte puțini dintre aceștia fiind de origine română.

$19 * * *$ Notă BOR-Sofia către MAE, nr. 27/25.06.2013.

20 *** Despre comunitatea românească din Bulgaria, disponibil la http://sofia.mae.ro/node/804 (accesat la data de 30.10.2021). 


\section{Scurtă istorie a Bisericii Ortodoxe Române din Sofia}

Biserică Ortodoxă Română cu hramul „Sfântă Treime” din Sofia este unul dintre locașurile de cult cu renume ale capitalei, remarcându-se prin mărimea, originalitatea construcției şi împodobirea ei interioară. Biserica este unul dintre locașurile de cult întreținute peste hotare de Patriarhia Română, respectiv Statul Român, cu scopul cultivării legăturilor de prietenie şi colaborare cu bisericile creștine pe teritorii cărora se găsesc, pentru satisfacerea nevoilor religioase ale creștinilor de origine română. În legătură cu ridicarea bisericii românești din Sofia şi sfințirea acesteia, la arhiva centrală de stat sunt puse la dispoziție peste 250 de file ${ }^{21}$ care urmează să fie cercetate în profunzime şi publicate.

Construcția bisericii românești din Sofia a fost inițiată cu fondurile donate de comunitatea aromână din Sofia ${ }^{22}$, fiind continuată şi definitivată cu ajutorul generos al Statului Român ${ }^{23}$, pe al cărui nume figurează actul de proprietate. Dintre donatorii aromâni amintim pe Gachi Trifon Ciomu, Gheorghe Paligora, Ioan (Jan) Ghiulamila, Teodor Bandu, Dumitru şi Nicolae Kiurkci, Taşcu Ionescu, Alexandru Calciu și Spiridon Ghionda ${ }^{24}$.

În nota nr. 8 din 21 decembrie 1912, ministrul plenipotențiar al României din Bulgaria a constatat că a fost construită o biserică (precum şi anexele necesare) în urma autorizației Ministerului Afacerilor de Externe ${ }^{25}$ şi a Guvernului Bulgar ${ }^{26}$, fiind pe deplin terminată. De asemenea, la Ministerul de Externe Român a fost identificat răspunsul original semnat de Președintele Consiliului, prin care se face cunoscut că legea constitutivă a Exarhatului nu prevede nicio autorizație specială din partea Sfântului Sinod Bulgar,

21 *** Фонд 166 К, оп. 1 , a.e. 1066.

22 Un aspect important al identificării aromânilor este apartenența lor la confesiunea ortodoxă.

${ }^{23}$ Vezi mai mult în: Георги Барболов, op. cit., p. 121.

$24 * * *$ Notă BOR-Sofia către MAE, Nr. 27/25.06.2013.

25 Adresa nr. 4802 din 15 martie 1904.

${ }^{26}$ Nota Ministrului Afacerilor Externe din Bulgaria, nr. 991 din 15/27 iulie 1904. 
mai cu seamă pentru clădirea bisericilor legațiunilor acreditate în Bulgaria $^{27}$. Din dosarele referitoare la biserica românească din Sofia s-a constatat faptul că, în 1904, Guvernul Bulgar (Ministerul Afacerilor Externe şi al Cultelor) a înștiințat Sfântul Sinod al Bisericii Ortodoxe Române de consimțământul oferit spre a fi edificată biserica. Trebuie să menționăm faptul că pentru biserica Legației Imperiale Ruse s-a procedat la fel ${ }^{28}$.

Pe lângă Biserica românească „Sfânta Treime” din Sofia, la aceeași adresă au mai fost construite ulterior şi alte dependințe, respectiv casa parohială (locuința de serviciu), fostul liceul românesc din Sofia, sala de gimnastică a liceului, precum şi o anexă (acum rămasă parohiei). Terenul cumpărat a fost dobândit prin actele de vânzare-cumpărare nr. 201 din 7 martie 1905 pentru 87 m² de teren, nr. 202 din 7 martie 1905 pentru $2455 \mathrm{~m}^{2}$ de teren şi trei case vechi - ulterior demolate, precum şi nr. 278 din 22 martie 1905 pentru 74,30 $\mathrm{m}^{2}$ de teren. Actele notariale au fost emise de notariatul de pe lângă Tribunalul Regional din Sofia şi se găsesc în dosarele nr. 287, 288 şi 368 din 1905.

Biserică românească „Sfântă Treime” din Sofia are statutul de biserică reprezentativă a Patriarhiei Române, respectiv a Statului Român, pe lângă Patriarhia Bulgară, recunoscută cu drepturi depline. De la înființarea acesteia şi până astăzi funcționează neîntrerupt, fiind condusă de preoți trimiși de către Patriarhia Română. preoții:

Astfel, din anul 1923 şi până în prezent au slujit următorii

1.Ion Sagala Iliescu (?);

2.Stelian Angelescu (1923-1925);

3.Ion Popescu-Runcu (1928-1948);

4.Nicolae Grosu (1926);

5.Dimitâr Poppetrov (1928-1948);

6.Ion Dorobanțu (1933-1942);

7.Ion Cristea (1942-1968);

$27 * * *$ Arhivă MAE, fond 15, vol. 17, fila 66 .

28 *** Notă BOR-Sofia către MAE, nr. 27/25.06.2013. 
8.Alexandru Munteanu (1968-1980);

9.Arman Munteanu (1980-1986);

10. Alexandru Șchiopu (1986-1993);

11. Sorin-Ilie Cormoș (1993-1994);

12. Neluțu Oprea (1995-prezent).

Aflându-se în centrul orașului Sofia, biserică românească este frecventată la slujbe de mulţi credincioși bulgari. Prima cerere pentru construirea bisericii românești din Sofia, pe care o găsim la Arhiva centrală de Stat, este din data de 16/29 iunie 1904, piatra de temelie a locașului fiind așezată la data de 9 mai 1905. Construcția a durat până în anul 1908, iar sfințirea bisericii a fost întârziată pe de-o parte din cauza schismei în care se găsea Biserica Ortodoxă din Bulgaria, iar, pe de altă parte, din cauza războaielor balcanice. Biserica a fost finalizată și pregătită pentru sfințire în anul 1912, iar în toamna aceluiași an a izbucnit războiul. În perioada 1913-1921, probabil tot din cauza războaielor, biserica a fost ocupată de grecocatolici ${ }^{29}$.

Sfinţirea bisericii a avut loc la sărbătoarea Sfântului Nicolae, pe data de 6/23 decembrie 1923, în cadrul unei slujbe solemne oficiate de reprezentanți ai celor două Biserici Ortodoxe Surori - română şi bulgară. Delegația română care a luat parte la sfințirea bisericii a fost condusă de către Episcopul Visarion Puiu al Hotinului (1923-1935), ierarhul având şi responsabilitatea pentru refacerea legăturii dintre cele două Biserici, întreruptă din cauza războaielor. Refacerea acestei legături se pecetluiește prin actul de sfințire a bisericii românești „Sfânta Treime” din Sofia. Evenimentul a fost pe larg mediatizat în presa bisericească din Bulgaria, aproape întregul număr 44 al Ziarului Bisericesc din 22 decembrie 1923 fiind dedicat acestui eveniment. Sfințirea a fost prezidată de către Mitropolitul Ştefan al Sofiei şi Episcopul Visarion al Hotinului, împreună cu un număr mare de clerici români şi bulgari.

29 Vezi în Toma KIURKCIEV / Nicolay KIURKCIEV, Istoria comunității românești din Sofia: Prezentare istorică, acte, evenimente..., p. 9. 
Slujba a fost oficiată în ambele limbi, română şi bulgară, fiind, de asemenea, prezent și corul Catedralei Mitropolitane la respectiva sărbătoare. Oficialitătile din partea bulgară au fost: Mitropolitul Boris al Ohridului, Hristo Popov, Secretarul Sfântului Sinod, domnul Kalfov, Ministrul Afacerilor Externe şi al Cultelor, împreună cu oficialități de rang înalt din cadrul Ministerului. Importanța deosebită a sărbătorii de sfințire a bisericii românești și marea bucurie de care au avut parte Biserica Ortodoxă din Bulgaria şi poporul bulgar au fost exprimate în discursul rostit de către Mitropolitul Boris al Ohridului în timpul agapei oferite de către delegația română cu ocazia sfințirii bisericii: „Românii, care sunt concetățenii noștri buni, au deja o biserică dedicată în numele Bunului Dumnezeu Cel în Treime Slăvit, unde vor asculta cuvântul Domnului și slujbele în limba lor maternă. Și, ceea ce este şi mai important, această sfințire s-a săvârșit de către ierarhi bulgari şi români, de clerici bulgari şi români şi în acest fel s-a confirmat din nou fraternitatea, unitatea spirituală, unitate completată de credința comună a celor două popoare vecine" ${ }^{30}$. Mitropolitul Maxim al Plovdivului 1-a salutat pe Episcopul Visarion cu aceste cuvinte: „Vizita Preasfinției Voastre și sfințirea bisericii în capitala noastră să fie un mijloc fericit şi haric al unităţii şi comuniunii dintre cele două Biserici - Română şi Bulgară - şi între cele două popoare român şi bulgar”. Episcopul Visarion a afirmat la rândul său faptul că „știe bine situația în care se afla Biserica Ortodoxă din Bulgaria, dar, cu toate acestea, am venit cu dragoste adevărată la voi şi poate că Dumnezeu a hotărât ca eu să fiu prima rândunică de primăvară care aduce vestea cea bună pentru unitatea frățească dintre cele două Biserici”31. La zece ani de la sfințire, Episcopul Visarian publica la tipografia Statului din Chișinău amintirile referitoare la acest eveniment, împreună cu cuvântul de învățătură rostit cu acel prilej, în lucrarea "Sfințirea bisericii românești din Sofia", îndemnând ambele popoare la unire: „Dunărea, din care de obicei facem hotar despărțitor, precum adună şi unește apele sale în chip

30 *** ЦВ, Бр. 44 от 22 декември 1923 год.

${ }^{31}$ Ibidem, p. 2. 
egal şi din Carpaţi, şi din Balcani, tot aşa ne cheamă simbolic şi pe noi, popoarele din văile lor, la unire" 32 .

Planul architectural al bisericii aparține arhitectului austriac Friedrich Grünanger ${ }^{33}$, construcția propriu-zisă fiind executată din cărămidă şi beton de către constructorul bulgar Vasil Gligov pentru suma de 35.548 leva (la valoarea din anul 1902). Stilul bisericii este cel brâncovenesc (secolul XVIII), în formă de corabie cu trei turle. Biserica a fost pictată în întregime, în stilul neobizantin, cu bogate ornamentații în tempera, cu capiteluri şi fresce decorative de o impresionantă frumusețe.

Pictura a durat până în anul $1924^{34}$ și a fost executată de maeștri emeriţi ai timpului: Vermont, Artaquino şi profesorul Serafim de la Şcoala Belle Arte din București. Catapeteasma ${ }^{35}$, baldachinul din Sfântul Altar şi întregul mobilier din interior au fost lucrate din lemn de stejar cu bogate ornamentații. Biserica este luminată de cinci policandre din cristal vienez, cumpărate la vremea aceea din Austria, la început șapte la număr, ulterior rămânând doar cinci, două fiind distruse în anul 1945, în timpul războiului. Soleea are trei trepte din marmură neagră, restul suprafeței interioare fiind acoperită cu mozaic.

În luna martie a anului 1944, turla centrală a bisericii a fost distrusă de un bombardament, fiind restaurată în anul 1945, când a fost refăcută şi pictura murală. Lucrările de renovare au costat trei milioane de leva (la valoarea vremii), suma fiind suportată în

32 Visarion, Episcop de Hotin, Sfințirea bisericii românești din Sofia, Tipografia Statului Chișinău, 1933, p. 17.

33 Născut la Sighișoara, în anul 1856, Friedrich Grünanger a fost un arhitect austro-ungar care a lucrat și în Bulgaria. A proiectat și construit numeroase clădiri rezidențiale şi publice remarcabile, în principal în Sofia, printre care și clădirea Facultății de Teologie din cadrul Universității din Sofia, Seminarul din Sofia cu Biserica Sfântul Ioan Botezătorul, Sinagoga din Sofia, Băile minerale din Sofia și Palatul Eegal.

34 Георги Барболов, op. cit., p. 121.

35 Aceeași catapeteasmă cu icoanele respective, dar în mărime mai mică, încadrează şi înnobilează Sfântul Altar din Mausoleul de la Grivița, închinat în cinstea eroilor români, căzuți pentru eliberarea Bulgariei de sub jugul otoman, aceasta denotând faptul că respectivii maeștri au fost aceiași români. 
întregime de către Statul Român. În data de 18 iunie 2000, după o restaurare amplă, biserica a fost resfințită în cadrul unei slujbe solemne, oficiată de Întâistătătorii celor două Biserici Surori Română şi Bulgară -, Teoctist şi Maxim.

Vorbind despre istoria Bisericii Ortodoxe Române şi Parohia „Sfânta Treime” din Sofia, este important să menționăm și faptul că ansamblul coral al bisericii a fost recunoscut drept unul dintre cele mai profesioniste și renumite coruri bisericești din Sofia. Fondatorul şi primul dirijor al corului este părintele Ion Popescu Runcu, ajuns în Bulgaria în anul $1924^{36}$. Mulți dintre coriști au făcut carieră remarcabilă în străinătate. În acest sens, amintirile lui Nicola Ribarov (1914-1998) - din 1943 corist, iar între 1953 și 1998 dirijor al corului - au o valoare deosebită pentru istoria acestei biserici ${ }^{37}$.

În prezent Biserica Ortodoxă Română cu hramul „Sfânta Treime" din Sofia rămâne singura legătură culturală şi spirituală care îi unește pe toți românii din Sofia și care cuprinde promovarea culturii românești în Sudul Dunării. Biserica „Sfânta Treime” este și centrul spiritual al comunității românești din Sofia, ajutându-i în acelaşi timp pe aromâni să-şi păstreze identitatea și limba lor maternă. În acest fel, biserica a rămas singurul centru de cultură românească, iar pentru aromânii din Sofia singurul loc unde se poate vorbi graiul strămoșilor.

$\cos 8$

\section{Bibliografie}

1. *** Arhivă MAE, fond 15, vol. 17, fila 66 .

2. Барболов, Георги. Историята на армъните $u$ взаимоотношенията им с българите. С., 2000.

36 Mai multe detalii privind activitatea lui Ion Runcu, vezi: Mircea Valeriu DiACONESCU, Ion Runcu. Omagiu la implinirea a 40 de ani de la moartea compozitorului. Amintiri, biografie, clasificare, inregistrări, disponibil la https://no14plusminus.files.wordpress.com/2015/11/mircea-valeriu-diaconescu -ion-runcu-40-de-ani-de-la-moartea-compozitorului.pdf (accesat la data de 12.10.2021).

${ }^{37}$ Георги Барболов, ор.cit., p. 163-170. 
3. BANDU, Gh., „Aromânii din Sofia”, în Deșteptarea, 12/1992.

4. *** Despre comunitatea românească din Bulgaria, disponibil la http://sofia.mae.ro/node/804 (accesat la data de 30.10.2021).

5. DiACONESCU, Mircea Valeriu, Ion Runcu. Omagiu la implinirea a 40 de ani de la moartea compozitorului. Amintiri, biografie, clasificare, inregistrări, disponibil la https://no14plusminus. files.wordpress.com/2015/11/mircea-valeriu-diaconescu-ionruncu-40-de-ani-de-la-moartea-compozitorului.pdf (accesat la data de 12.10.2021).

6. *** Фонд 166К, оп. 1, a.e. 1066.

7. FERMENDZIN, Eusebius Martin, Acta Bulgariae Ecclesiastica, Zagrebae, 1887.

8. GHIULAMILA, I. G., „Românii macedonieni din Bulgaria (Aromânii)", în Graiul Românesc, 2/1928.

9. HRISTU, Vasile, „Aromânii din Bulgaria”, în Graiul Românesc, 6$7 / 1931$.

10. IDEM, „Comunitatea românească din Sofia”, în Toma KIURKCIEV / Nicolay KIURKCIEV, Istoria comunității românești din Sofia Prezentare istorică, acte, evenimente, Sofia, 2001.

11. Кирилова, А., Родовата памет на армъните, В: Георгиева, Ив. /съст./. Армъните в България. С., 1998.

12. Кюркчиев, Николай, Армъните - етнос и език с 2000 годишна история, în Toma KIURKCIEV / Nicolay KIURKCIEV, Istoria comunității românești din Sofia - Prezentare istorică, acte, evenimente, Sofia, 2001.

13. *** Nota Ministrului Afacerilor Externe din Bulgaria, nr. 991 din 15/27 iulie 1904.

14. *** Notă BOR-Sofia către MAE, nr. 27/25.06.2013.

15. Нягулов, Б. Проблемът за власите в България между двете световни войни: политически фактори и аспекти, В: Българска етнология. Г. ХХІ, извънреден брой, С. 1955.

16. *** ЦВ, Бр. 44 от 22 декември 1923 год.

17. VISARION, Episcop de Hotin, Sfințirea bisericii românești din Sofia, Tipografia Statului Chișinău, 1933. 